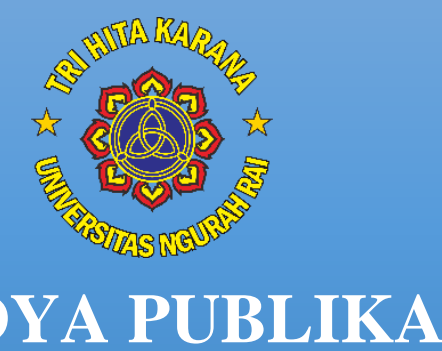

\title{
PENGARUH DISIPLIN KERJA, MOTIVASI DAN KOMUNIKASI TERHADAP KINERJA PEGAWAI NEGERI SIPIL PADA UNIT PELAKSANA TEKNIS MUSEUM BALI
}

\author{
I Wayan Agus Suwiana Putra \\ Pepo Group Poperty; email : agus.suwiana2013@gmail.com
}

\begin{abstract}
The Technical Implementation Unit (UPT) of the Bali Museum was one of the museums in Bali that holds relics from the past of people and ethnography. The purpose of establishing the Bali Museum was to accommodate, store and preserve historical objects from Balinese culture and local wisdom in the past in order to provide torches for present and future generations. As one of the organizations whose mission is to preserve Balinese culture and local wisdom, the Bali Museum was expected to be able to improve the performance of introducing Balinese culture in the past to the Balinese people, especially the young generation today so as not to forget the local Balinese culture. As we know that the performance of an organization is largely determined by the performance of employees in the organization. Therefore UPT. The Bali Museum continues to evaluate especially the available resources so that employee performance can improve. The purpose of this study was to determine whether there was a positive and significant influence between the Work Discipline, Motivation and Communication variables with the Performance of Civil Servants in the Technical Implementation Unit of the Bali Museum and to find out the most dominant variables affecting performance in the agency.

By using the Quantitative Descriptive method, the sample was taken by means of the saturation sampling technique that was all civil servants at UPT. Bali Museum of 33 people. From the results of the study showed that the results of the analysis with statistical tests showed that work discipline variables had a positive effect on employee performance. This can be seen from the significant value of $0.026<0.05$ (the significant value determined) and the t-test results of 2.341. Likewise, the motivation variable gets a significant result of 0.020 and the t-test value of 2.452 can be analyzed that motivation has a positive effect on employee performance. The communication variable on performance shows a significant result of 0.001 where the value of $r<0.05$ and $t$-test of 3.911. So communication also has a positive effect on employee performance. The influence of work discipline, motivation and communication on employee performance, obtained a significant value of 0,000 ( $p \leq 0.005)$, and the F-test value obtained by 133.540 is greater than the F-table of 2.93 then $\mathrm{Ho}$ is rejected, meaning there was a positive influence from work discipline, motivation and communication on employee performance, as well as from the results of the study also showed that the most dominant variable affecting performance was the communication variable because
\end{abstract}


ISSN : 2338-2554

based on standardized coefficient analysis calculations beta had the largest value of 0.430 (43\%) compared to the work discipline variable 0.265 (26\%) and motivation variables of 0.321 (32\%).

Keywords: Work Discipline, Motivation, Communication and Performance

\begin{abstract}
Abstrak
Unit Pelaksana Teknis (UPT) Museum Bali adalah salah satu museum di bali yang menyimpan peninggalan masa lampau manusia dan etnografi. Tujuan didirikannya museum bali adalah untuk menampung, menyimpan dan melestarikan benda-benda sejarah dari kebudayaan dan kearifan lokal bali di masa lampau agar dapat memberikan suluh bagi generasi sekarang dan mendatang. Sebagai salah satu organisasi yang memiliki misi melestarikan budaya dan kearifan lokal bali saat ini, museum bali diharapkan mampu meningkatkan kinerja untuk mengenalkan kebudayaan bali di lampau kepada masyarakat bali khususnya generasi muda saat ini agar tidak lupa dengan budaya lokal bali. Seperti yang kita ketahui bahwa kinerja suatu organisasi sangat di tentukan oleh kinerja dari pegawai di organisasi tersebut. Oleh sebab itu UPT. Museum Bali terus melakukan evaluasi khususnya terhadap sumber daya yang ada sehingga kinerja pegawai dapat meningkat. Tujuan dari penelitian ini untuk mengetahui apakah terdapat pengaruh positif dan signifikan antara variabel Disiplin Kerja, Motivasi dan Komunikasi dengan Kinerja Pegawai Negeri Sipil pada Unit Pelaksana Teknis Museum Bali serta untuk mengetahui variabel yang paling dominan mempengaruhi kinerja di instansi tersebut.

Dengan menggunakan metode Deskriptif Kuantitatif, sampel di ambil dengan cara teknik sampling jenuh yaitu seluruh pegawai negeri sipil di UPT. Museum bali yang berjumlah 33 orang. Dari hasil penelitian menunjukkan bahwa hasil analisis dengan uji statistik memperlihatkan variabel disiplin kerja berpengaruh positif terhadap kinerja pegawai. Hal ini terlihat dari nilai signifikannya sebesar 0,026 $<0,05$ (nilai signifikan yang ditetapkan) serta hasil t-test sebesar 2,341. Demikian juga variabel motivasi mendapatkan hasil signifikan sebesar 0,020 dan nilai t-test sebesar 2,452 dapat di analisis bahwa motivasi berpengaruh positif terhadap kinerja pegawai. Variabel komunikasi terhadap kinerja menunjukkan hasil signifikannya sebesar 0,001 dimana nilai $\mathrm{r}<0,05$ serta t-hitung sebesar 3,911. Jadi komunikasi juga berpengaruh positif terhadap kinerja pegawai. Pengaruh disiplin kerja, motivasi dan komunikasi terhadap kinerja pegawai , didapatkan nilai signifikannya sebesar $0,000(\mathrm{p} \leq 0,005)$, dan nilai F-test diperolah sebesar 133,540 lebih besar dari F-tabel sebesar 2,93 maka Ho di tolak, artinya ada pengaruh positif dari disiplin kerja, motivasi dan komunikasi terhadap kinerja pegawai, serta dari hasil penelitian juga menunjukkan bahwa variabel yang paling dominan mempengaruhi kinerja adalah variabel komunikasi karena berdasarkan perhitungan analisis standardized coeffecients beta memiliki nilai terbesar yakni 0,430 (43\%) dibandingkan dengan variabel disiplin kerja 0,265 (26\%) dan variabel motivasi sebesar 0,321 (32\%).
\end{abstract}

Kata Kunci : Disiplin Kerja, Motivasi, Komunikasi dan Kinerja

\title{
1. PENDAhUluan
}

\subsection{Latar Belakang Masalah}

Manusia sebagai mahluk sosial tidak lepas dari kehidupan berorganisasi, bahkan sejak manusia itu dilahirkan sekalipun, maka dia telah masuk dalam suatu organisasi. "Organisasi adalah bentuk persekutuan dua orang atau lebih yang bekerja bersama serta secara formal terikat dalam rangka pencapaian suatu tujuan 
yang telah ditentukan dalam ikatan yang terdapat seorang/beberapa orang yang disebut atasan dan seorang/kelompok orang yang disebut bawahan" (Siagian 2006:6).

Jadi organisasi merupakan suatu wadah beberapa orang yang memiliki tujuan dan pola pikir yang sama dan sama-sama ingin mencapai tujuan yang sama. Setiap organisasi memiliki berbagai macam bagian penting untuk dapat menunjang berlangsungnya kegiatan perusahaan dan membantu dalam mencapai tujuan perusahaan. Sumber daya manusia adalah salah satu dari berbagai macam bagian penting tersebut. Manusia adalah komponen terpenting penggerak perusahaan. Manusia yang merumuskan strategi dalam organisasi, manusia yang melakukan proses produksi, manusia yang melayani konsumen, dan pada akhirnya manusialah faktor utama terwujudnya tujuan suatu organisasi..

Sumber daya manusia sangat penting dalam suatu organisasi, maka sebuah organisasi dipandang perlu untuk dapat mengatur dan mendayagunakannya dengan baik agar tujuan organisasi tercapai. Tujuan organisasi akan lebih mudah tercapai bila karyawannya memiliki prestasi yang baik. Sumber daya manusia adalah komponen utama suatu organisasi yang menjadi perencana dan berperan aktif dalam setiap aktifitas organisasi. Dengan pikiran, ,perasaan, keinginan, status dan latar belakang pendidikan, usia, jenis kelamin yang berbeda-beda yang dibawa ke dalam suatu organisasi sehingga tidak seperti mesin, uang dan material, yang sifatnya pasif dan dapat dikuasai dan diatur sepenuhnya dalam rangka mewujudkan apa yang menjadi tujuandari organisasi/instansi.

Demikian pula dengan pegawai negeri sipil merupakan sumber daya manusia yang menjadi pelaksana dan pengendali semua proses pencapaian tujuan pemerintahan. Sumber daya manusia yang dimiliki suatu instansi, dimana dalam mencapai tujuan nasional dibutuhkan pegawai negeri sipil yang mampu dan siap menghadapi tantangan masa depan serta siap akan adanya berbagai perubahanperubahan dalam menghadapi era globalisasi. Pegawai negeri sipil merupakan sumber daya aparatur negara yang bertugas memberikan pelayanan kepada masyarakat secara profesional, jujur, adil dan merata dalam penyelenggaraan tugas negara. 
Menurut Undang-undang Nomor 43 Tahun 1999 tentang pokok-pokok Kepegawaian yang menyebutkan: " kedudukan dan peranan pegawai negeri adalah penting dan menentukan, karena pegawai negeri sebagai aparatur negara, abdi negara dan abdi masyarakat untuk menyelenggarakan pemerintahan dan pembangunan dalam rangka usaha mencapai tujuan nasional". Sesuai amanat Undang-undang, maka dibutuhkan produktivitas kerja pegawai negeri yang tinggi, yaitu kemampuan untuk memperoleh manfaat yang sebesar-besarnya dari sarana dan prasarana yang tersedia dengan menghasilkan output yan optimal. Produktivitas kerja yang tinggi dikalangan aparatur sudah semestinya dimiliki oleh pegawai negeri, sebagai perwujudan kesadaran dan tanggung jawabnya yang tinggi dalam mengabdikan dirinya pada kepentingan masyarakat, bangsa dan negara.

Proses pembangunan yang terjadi dalam dewasa ini dengan sistem demokrasi yang ada penerapan prinsip-prinsip good govermancedalam pengelolaan pemerintahan menjadi suatu tuntutan utama, karena masyarakat mulai kritis dalam memonitor dan mengevaluasi manfaat serta nilai yang diperoleh atas pelayanan dari instansi pemerintah, sehingga saat ini kinerja instansi pemerintah menjadi sorotan publik. Kinerja sebuah instansi pemerintahan sangat dipengaruhi oleh kinerja para pegawai yang ada di instansi tersebut. Oleh karena itu kinerja memiliki peran yang sangat penting di dalam manajemen dan organisasi, karena keberhasilan dalam suatu organisasi di tentukan oleh kinerja.

Secara konsepsional kinerja dapat dilihat dari dua segi, yaitu kinerja pegawai secara individu dan kinerja organisasi. Hal ini berarti, jika seseorang bekerja dalam organisasi, kinerjanya merupakan serangkaian perilaku dan kegiatan secara individual sesuai dengan tujuan organisasi. Kinerja dapat di artikan sebagai hasil kerja atau kemampuan pegawai dalam mencapai persyaratan-persyaratan pekerjaan yang diberikan baik dari segi kualitas maupun kuantitas. Kinerja juga bermakna sebagai sebuah ukuran terhadap hasil kerja pegawai, oleh karena itu kinerja pegawai dapat diartikan juga sebagai suatu kondisi yang menunjukkan kemampuan seorang pegawai dalam menyelesaikan setiap tugas yang telah dibebankan kepadanya. 
Wexley dan Yukl (2002 : 97), mengidentifikasi faktor-faktor yang mempengaruhi kinerja antara lain adalah disiplin kerja dan motivasi. Sedangkan menurut mangkunegara (2005 : 16-17), menyimpulkan faktor-faktor penentu prestasi kerja adalah faktor individu dan faktor lingkungan kerja organisasi, yang dimaksud antara lain uraian jabatan yang jelas, autoritas yang memadai, target kerja yang menantang, pola komunikasi yang efektif, hubungan kerja harmonis, iklim kerja respect dan dinamis, peluang berkarir dan fasilitas kerja yang relatif memadai.

Berkaitan dengan masalah kinerja, dalam rangka terlaksananya pemerintahan yang lebih berdaya guna dan berhasil guna, bersih, serta bertanggung jawab, telah diterbitkan Istruksi Presiden Nomor 7 tahun 1999 tentang Akuntabilitas Kinerja Instansi Pemerintah dalam mencapai misi organisasi dan tujuan-tujuan serta sasaran organisasi.Dalam upaya meningkatkan kinerja para pegawai maka perlu adanya disiplin kerja dari pada pegawai itu sendiri, motivasi dari pimpinan maupun diri sendiri dan komunikasi yang baik antar sesama pegawai maupun dengan pimpinan dalam setiap penyelesaian tugas-tugas yang ada.

Keberhasilan dalam melakukan pekerjaan dipengaruhi oleh disiplin kerja yang baik dari para pegawai. Menurut Rivai (2010:825), "Disiplin kerja adalah alat yang digunakan para manajer untuk berkomunikasi dengan karyawan agar mereka bersedia untuk mengubah suatu perilaku serta sebagai suatu upaya untuk meningkatkan kesadaran norma-norma sosial yang berlaku”. Sedangkan menurut Hasibuan (2009:193), “Disiplin merupakan kesadaran serta kesediaan seseorang untuk mentaati peraturan yang ada di dalam organisasi dan norma-norma sosial yang berlaku". Jadi di dalam membentuk sikap disiplin, seorang atasan harus dapat mengkomunikasikan segala norma-norma yang berlaku dalam organisasi agar membentuk kesadaran bawahannya untuk mematuhi aturan yang ada.

Asumsi bahwa pemimpin mempunyai pengaruh langsung atas sikap kebiasaan yang diperoleh karyawan. Kebiasaan itu ditentukan oleh pemimpin, baik dengan iklim atau suasana kepemimpinan maupun melalui contoh diri pribadi. Peran seorang pemimpin disini adalah memberi motivasi kerja kepada bawahannya agar dalam setiap penyelesaian tugas-tugasnya sesuai dengan yang diharapkan. 
Motivasi dari dalam diri setiap individu juga sangat diperlukan guna menunjang semangat kerja sehingga kinerja dari setiap individu bisa maksimal.

Menurut Wibowo (2003 : 379) mengemukakan bahwa : "Motivasi merupakan dorongan terhadap serangkaian proses perilaku manusia pada pencapaian tujuan". Sedangkan elemen yang terkandung dalam motivasi meliputi unsur membangkitkan, mengarahkan, menjaga, menunjukkan intesitas, bersifat terus menerus dan adanya tujuan. Motivasi sangat penting karena dengan motivasi ini diharapkan setiap individu pegawai mempunyai semangat kerja yang tinggi, dengan begitu akan tercipta kualitas kerja yang mendukung kinerja sebuah organisasi.

Dalam setiap kegiatan atau pelaksanaan tugas yang dilakukan oleh pegawai perlu adanya komunikasi, faktor komunikasi ini juga sangat berpengaruh terhadap kinerja para pegawai di suatu organisasi. Komunikasi secara umum adalah proses pemindahan informasi dari satu orang ke orang lainnya yang dapat berlangsung secara lisan ataupun tulisan dan dapat dilakukan oleh dua orang atau lebih. Komunikasi dalam suatu pekerjaan dapat dianalisis dari tiga tingkatan yaitu, komunikasi individu, komunikasi dalam kelompok, dan komunikasi keorganisasian. Hal ini berarti bahwa semua sumber daya manusia dituntut untuk menjadi orang yang komunikatif yang harus memiliki banyak informasi untuk disampaikan kepada orang lain.

Komunikasi yang baik akan memberikan dampak yang positif terhadap setiap penyelesaian tugas-tugas dari pegawai itu sendiri. Robbins (2006: 392) menyatakan "Salah satu kekuatan yang paling menghambat suksesnya kinerja pegawai adalah kurangnya komunikasi yang efektif ". Komunikasi yang efektif akan memudahkan setiap individu pegawai dalam suatu organisasi dalam menyelesaikan tugas-tugas yang telah dilimpahkan kepadanya. Dengan demikian kinerja dari para pegawai akan meningkat.

Mengingat pentingnya aspek disiplin kerja, Motivasi kerja dan kominikasi yang diterapkan dalam suatu organisasi yang dapat meningkatkan kinerja para pegawai dalam melaksanakan tugas-tugas dan selanjutnya menentukan produktivitas kerja, Selain itu sebagai salah satu lembaga teknis di lingkungan 
Pemerintah Provinsi Bali yang sering bersentuhan langsung dengan lingkungan masyarakat umum (Publik), sudah selayaknya dicermati tentang Kinerja pegawai di lembaga tersebut. Maka dalam hal ini dilakukan penelitian pada suatu instansi pemerintah yaitu, Unit Pelaksana Teknis (UPT) Museum Bali.

Guna meningkatkan kinerja pegawai dilingkungan instansi bersangkutan untuk bekerja secara maksimal dan efisien dalam memanfaatkan sumber daya yang ada, perlu dukungan berbagai faktor seperti, pengaturan jam kerja yang jelas untuk penyelesaian setiap tugas yang dilimpahkan kepada para pegawai, adanya bimbingan dari seorang pimpinan guna meningkatkan kinerja para pegawai dan adanya koordinasi dalam setiap kegiatan kedinasan.

Dari hasil penelitian dan observasi penulis di lapangan masih ditemukan masalah-masalah yang terkait dengan belum optimalnya kinerja para pegawai di Unit Pelaksana Teknis Museum Bali. Hal ini dapat dilihat dari adanya pegawai yang kurang menyadari bahwa tugas yang diberikan kepadanya merupakan suatu kewajiban yang harus dilaksanakan dan dipertanggungjawabkan, tetapi kenyataannya masih ada pegawai yang menyerahkan tugasnya kepada orang lain dengan berbagain alasan. Dari segi disiplin,Kurang efektifnya jam kerja para pegawai, hal inidapat dilihat dari adanya pegawai yang tidak ada di tempat saat jam kerja.

Dari segi motivasi pimpinan terhadap para bawahannya, maupun motivasi dari dalam diri pegawai itu sendiri, misalnya semangat kerja yang rendah dan penyelesaian tugas yang masih belum maksimal dari para pegawai.Dan dari segi komunikasi, minimnya komunikasi antar para pegawai maupun pegawai dengan pimpinan dalam setiap pelaksanan tugas-tugasnya, sehingga dalam setiap penyelesaian tugas belum bisa terselesaikan secara maksimal.

Melihatdari permasalahan diatas, maka studi ini memfokuskan pada pengaruh disiplin kerja, motivasi kerja dan komunikasi terhadap kinerja pegawai negeri sipil. Keberadaan disiplin kerja, motivasi kerja dan komunikasi dalam hal ini adalah sebagai variabel bebas (Independent Variables), dan Kinerja pegawai sebagai variabel terikat (Dependent Variables). 


\subsection{Rumusan Masalah}

Berdasarkan uraian pada latar belakang masalah tersebut, adapun rumusan masalah di dalam penelitian ini adalah :

1. Apakah terdapat pengaruh positif dan signifikan antara Disiplin kerja dengan Kinerja Pegawai Negeri Sipil pada Unit Pelaksana Teknis Museum Bali?

2. Apakah terdapat pengaruh positif dan signifikan antara Motivasi Kerja dengan Kinerja Pegawai Negeri Sipil pada Unit Pelaksana Teknis Museum Bali Dinas?

3. Apakah terdapat pengaruh positif dan signifikan antara Komunikasi dengan Kinerja Pegawai Negeri Sipil pada Unit Pelaksana Teknis Museum Bali?

4. Apakah terdapat pengaruh positif dan signifikan secara simultan antara Disiplin Kerja, Motivasi dan Komunikasi dengan Kinerja Pegawai Negeri Sipil pada Unit Pelaksana Teknis Museum Bali?

5. Manakah variabel yang paling dominan berpengaruh terhadap Kinerja Pegawai Negeri Sipil pada Unit Pelaksana Teknis Museum Bali?

\section{METODE PENELITIAN}

Dalam penelitian ini menggunakan jenis penelitian Kuantitatif. "Penelitian Kuantitatif adalah penelitian ilmiah yang sistematis terhadap bagian-bagian dan fenomena serta hubungan-hubungannya. Menurut (Kasiram, 2008) mendefinisikan penelitian kuantitatif adalah metode penelitian yang menggunakan proses data-data yang berupa angka sebagai alat menganalisis dan melakukan kajian penelitian, terutama mengenai apa yang sudah diteliti.Penelitian ini dimaksudkan untuk dapat memahami, menggambarkan dan menganalisa Pengaruh Disiplin Kerja, Motivasi dan Komunikasi terhadap Kinerja Pegawai Negeri Sipil pada Unit Pelaksana Teknis Museum Bali. Jumlah populasi pada penelitian ini berjumlah 34 orang. Dengan sampel 33 orang pegawai negeri sipil.

\section{DEFINISI KONSEPSIONAL}

1. Disiplin Kerja Menurut Alfred R. Lateiner dalam Imam Soejono (1983:72)

Disiplin kerja merupakan suatu kekuatan yang berkembang dalam tubuh individu sendiri, menyebabkan pekerjaan dapat menyesuaikan diri dengan sukarela pada keputusan, peraturan-peraturan dan nilai-nilai yang 
tertinggi dari pekerjaan dan tingkah laku dengan harapan pekerjaan yang akan dilakukan seefektif dan seefisien mungkin.

2. Motivasi Menurut Malayu S.P. Hasibuan (2005:143)

Motivasi adalah pemberian daya penggerak yang menciptakan kegairahan kerja seseorang agar mereka mau bekerja sama, bekerja efektif dan terintegrasi dengan segala daya upayanya untuk mencapai kepuasan.

3. Komunikasi Menurut Stewart L. Tubbs dan Sylvia Moss (1974)

Komunikasi ialah proses pembentukan makna diantara dua orang atau lebih.

4. Kinerja Pegawai Menurut Robbins, (2006:260)

Kinerja adalah suatu hasil yang dicapai oleh pekerja dalam pekerjaannya menurut kriteria tertentu yang berlaku untuk suatu pekerjaan.

\section{DEFINISI OPERASIONAL}

Definisi operasional adalah definisi yang didasarkan atas sifat-sifat variabel yang diamati. Adapun variabel penelitian, indikator dalam penelitian ini adalah sebagai berikut

1) Variabel Disiplin Kerja (X1)

1. Para pegawai datang ke kantor dengan tertib, tepat waktu dan teratur.

2. Berpakaian rapi di tempat kerja

3. Menggunakan perlengkapan kantor dengan hati-hati

4. Mengikuti cara kerja yang ditentukan oleh organisasi

5. Memiliki tanggung jawab

2) Variabel Motivasi (X2)

1. Tanggung Jawab (Responbility)

2. Prestasi yang diraih (Achievement)

3. Pengakuan orang lain (Recognition)

4. Pekerjaan itu sendiri (The work it self)

5. Kemajuan (Advancement)

3) Variabel Komunikasi (X3)

1. Pengertian

2. Kesenangan

3. Pengaruh sikap 
4. Hubungan sosial yang baik

5. Tindakan

4) Variabel Kinerja (Y)

1. Kualitas

2. Kuantitas

3. Ketepatan waktu

4. Efektivitas

5. Kemandirian

\section{TENIK ANALISA DATA}

Cara yang ditempuh dalam melakukan pengolahan data penelitian ini, dapat dijelaskan tahapannya sebagai berikut ini.

1. Pemberian Skor ( Skala Likert)

2. Uji Validitas \& Reliabilitas

3. Analisis Inferensial

4. Uji Statistik (F-Test)

5. Uji Statistik (t-Test)

6. Uji Multikolineritas

7. Uji Heteroskedastisitas

8. Uji Normalitas

\section{PEMBAHASAN}

\subsection{Pengaruh Disiplin Kerja Terhadap Kinerja Pegawai Negeri Sipil Pada} Unit Pelaksana Teknis Museum Bali.

Hasil uji secara parsial diperoleh nilai t-hitung untuk disiplin kerja sebesar 2,341 dengan nilai signifikan sebesar 0,026. Karena nilai signifikansinya lebih kecil dari 0,05 berarti terdapat pengaruh yang positif dan signifikan antara disiplin kerja terhadap kinerja pegawai negeri sipil. Hal ini berarti semakin baik disiplin kerjanya, maka semakin tinggi kinerja pegawai negeri sipil itu sendiri. Hasil ini didukung oleh pernyataan Fathoni (2006: 172) kedisiplinan merupakan fungsi operatif manajemen sumber daya manusia terpenting karena semakin baik disiplin karyawan, semakin tinggi prestasi yang dapat dicapainya. Menurut Hasibuan 
(2000) dalam putri (2013) menyatakan kesadaran adalah sikap seseorang yang secara sukarela mentaati semua peraturan dan sadar akan tugas serta tanggung jawabnya. Kedisiplinan adalah suatu sikap, tingkah laku dan perbuatan seseorang yang sesuai dengan peraturan baik yang tertulis maupun tidak tertulis. Kedisiplinan dapat diartikan bilamana pegawai datang dan pulang tepat pada waktunya, mengerjakan semua pekerjaannya dengan baik, mentaati semua peraturan dan norma-norma yang berlaku pada sebuah organisasi. Kedisiplinan adalah yang utama dalam sebuah organisasi karena dengan dukungan disiplin kerja yang baik maka akan meningkatkan kinerja sebuah organisasi untuk mencapai tujuannya. Jadi, kedisiplinan adalah kunci keberhasilan suatu instansi dalam mencapai tujuannya.

\subsection{Pengaruh Motivasi Terhadap Kinerja Pegawai Negeri Sipil Pada Unit Pelaksana Teknis Museum Bali.}

Hasil uji secara parsial diperoleh nilai t-hitung untuk variabel motivai sebesar 2,452 dengan nilai signifikan sebesar 0,020. Karena nilai signifikan lebih kecil dari 0,05 berarti terdapat pengaruh yang positif dan signifikan antara motivasi terhadap kinerja pegawai. Semakin baik motivai maka semakin baik kinerja pegawai. Menurut Herzberg dalam Hasibuan (2012:157-158) menyatakan bahwa faktor motivasi (motivation factors) merupakan faktor yang menyangkut kebutuhan psikologis seseorang adalah faktor yang meliputi serangkaian kondisi instrinsik, kepuasan pekerjaan, yang apabila terdapat didalam pekerjaan akan menggerakkan tingkat motivasi yang kuat, yang dapat menghasilkan prestasi pekerjaan yang baik. Cara terbaik untuk memotivasi pegawai/karyawan adalah dengan memberikan sebuah tantangan kerja dan kesempatan guna mencapai keberhasilan dalam pekerjaannya.

\subsection{Pengaruh Komunikasi Terhadap Kinerja Pegawai Negeri Sipil Pada Unit Pelaksana Teknis Museum Bali.}

Hasil uji secara parsial diperoleh nilai t-hitung untuk variabel komunikasi sebesar 3,911 dengan nilai signifikan sebesar 0,001 lebih kecil dari nilai signifikan 
yaitu 0,005 yang berarti terdapat pengaruh yang positif dan signifikan antara komunikasi terhadap kinerja pegawai. Semakin baik komunikasi maka akan semakin baik pula kinerja pegawai. (Handoko, 2009). Mengemukakan bahwa komunikasi juga sangat diperlukan bagi para pegawai dalam melaksanakan setiap kegiatan dan aktivitasnya. Dengan terjalinnya komunikasi yang baik diantara pegawai dapat menimbulkan kinerja yang lebih baik sehingga akan mengurangi tingkat penurunan kinerja dari pegawai pada instansi-instansi pemerintahan. Menurut Effendy, Robbins (2006:391) mengatakan bahwa komunikasi adalah proses penyampaian informasi, gagasan, fakta, pikiran dan perasaan dari satu orang ke orang lain. Dalam kehidupan organisasi, komunikasi menjadi sesuatu yang sangat penting karena komunikasi dapat meningkatkan saling pengertian antara atasan dan bawahan. Dalam hal ini pegawai dan pimpinan, dan meningkatkan koordinasi dari berbagai macam kegiatan/tugas yang berbeda. Penggunaan komunikasi yang baik akan mengurangi ketidakpastian, dan memperbaiki kinerja pegawai (Robbins, 2006:420).

\subsection{Pengaruh Disiplin Kerja, Motivasi Dan Komunikasi Terhadap Kinerja Pegawai Negeri Sipil Pada Unit Pelaksana Teknis Museum Bali.}

Hasil uji secara simultan diperoleh nilai F-hitung sebesar 133,540 dengan nilai signifikan sebesar 0,000. Karena nilai signifikansi lebih kecil dari 0,005 berarti terdapat pengaruh yang positif dan signifikan antara disiplin kerja, motivasi dan komunikasi terhadap kinerja pegawai negeri sipil pada Unit Pelaksana Teknis Museum Bali. Hasil ini didukung oleh Robbins (2006:260) bahwa indikator untuk mengukur kinerja karyawan secara individu. Ada 6 indikator yaitu kualitas, kuantitas, ketepatan waktu, efektivitas dan kemandirian.

\subsection{Variabel Bebas Yang Paling Dominan Mempengaruhi Kinerja Pegawai Negeri Sipil Pada Unit Pelaksana Teknis Museum Bali.}

Variabel di dalam penelitian ini adalah disiplin kerja, motivasi dan komunikasi. Diantara tiga variabel tersebut yang berpengaruh paling dominan terhadap kinerja pegawai negeri sipil pada unit pelaksana teknis museum bali 
adalah variabel komunikasi karena berdasarkan perhitungan nilai standardized coeffecient beta (Ghozali, 2006:42) diketahui variabel komunikasi memiliki koefesien beta yang terbesar yakni 0,430 dibandingkan dengan variabel disiplin kerja yang mempunyai koefesien beta sebesar 0,256 dan motivasi sebesar 0,321. Jadi di dalam penelitian ini faktor yang paling dominan berpengaruh terhadap kinerja pegawai negeri sipil adalah komunikasi.

\section{PENUTUP}

\subsection{Kesimpulan}

Penelitian ini bertujuan untuk mengetahui apakah ada pengaruh positif dan signifikan antara disiplin kerja dengan kinerja pegawai, motivasi dengan kinerja pegawai, komunikasi dengan kinerja pegawai serta secara bersama-sama antara disiplin kerja, motivasi dan komunikasi dengan kinerja pegawai serta mengetahui variabel yang paling dominan mempengaruhi kinerja pegawai di UPT. Museum bali. Berdasarkan hasil analisis data dan pembahasan dalam penelitian ini, maka dapat disimpulkan sebagai berikut:

1. Pengaruh variabel disiplin kerja secara parsial terhadap kinerja pegawai negeri sipil pada UPT. Museum Bali adalah positif dan signifikan. Hal ini di dasari akan hasil uji yang diperoleh dari koefesien regresi sebesar 0,180 dan hasil uji$\mathrm{T}$ dimana diperoleh nilai t-hitung untuk variabel disiplin kerja sebesar 2,341 dengan nilai signifikan sebesar 0,026. Oleh karena nilai signifikan lebih kecil dari 0,05 berarti terdapat pengaruh yang positif dan signifikan antara disiplin kerja dengan kinerja pegawai negeri sipil pada UPT. Museum Bali.

2. Pengaruh variabel motivasi secara parsial terhadap kinerja pegawai negeri sipil pada UPT. Museum Bali adalah positif dan signifikan. Hal ini di dasari akan hasil uji yang diperoleh dari koefesien regresi sebesar 0,164 dan hasil uji-T dimana diperoleh nilai t-hitung untuk variabel disiplin kerja sebesar 2,452 dengan nilai signifikan sebesar 0,020. Oleh karena nilai signifikan lebih kecil dari 0,05 berarti terdapat pengaruh yang positif dan signifikan antara motivasi dengan kinerja pegawai negeri sipil pada UPT. Museum Bali. 
3. Pengaruh variabel komunikasi secara parsial terhadap kinerja pegawai negeri sipil pada UPT. Museum Bali adalah positif dan signifikan. Hal ini di dasari akan hasil uji yang diperoleh dari koefesien regresi sebesar 0,303 dan hasil uji$\mathrm{T}$ dimana diperoleh nilai t-hitung untuk variabel disiplin kerja sebesar 3,911 dengan nilai signifikan sebesar 0,001. Oleh karena nilai signifikan lebih kecil dari 0,05 berarti terdapat pengaruh yang positif dan signifikan antara komunikasi dengan kinerja pegawai negeri sipil pada UPT. Museum Bali.

4. Pengaruh variabel disiplin kerja, motivasi dan komunikasi secara simultan terhadap kinerja pegawai negeri sipil pada UPT. Museum Bali adalah positif dan signifikan. Hal ini didasari dari hasil uji F diperoleh nilai F-hitung sebesar 133,540 dengan nilai signifikan sebesar 0,000. Karena nilai signifikan lebih kecil dari 0,05 berarti terdapat pengaruh yang positif dan signifikan secara bersama-sama antara disiplin kerja, motivasi dan komunikasi terhadap kinerja pegawai negeri sipil pada UPT. Museum Bali.

5. Diantara tiga variabel bebas yakni disiplin kerja, motivasi dan komunikasi yang paling dominan mempengaruhi kinerja pegawai negeri sipil pada UPT. Museum Bali adalah variabel komunikasi karena berdasarkan perhitungan nilai standardized coeffecient beta diketahui variabel komunikasi memiliki koefesien yang terbesar yakni 0,430 dibandingkan dengan variabel disiplin kerja yang memiliki nilai koefesien beta 0,256 dan variabel motivasi 0,321.

\subsection{Saran}

Adapun saran dari hasil penelitian ini yang dapat diuraikan sebagai berikut:

Bagi Unit Pelaksana Teknis (UPT) Museum Bali.

a. Untuk meningkatkan kinerja pegawai maka sebaiknya seorang pimpinan memberikan motivasi bagi setiap pegawai yakni memberikan bimbingan untuk mengembangkan pengetahuan kepada para pegawai dalam setiap penyelesaian tugas yang di embannya.

b. Untuk meningkatkan disiplin kerja pegawai maka seorang pimpinan wajib membuat sebuah peraturan dan nantinya jika ada pegawai yang melanggar akan dikenakan sanksi atau hukuman. 
c. Instansi atau organisasi diharapkan dapat meningkatkan komunikasi antar pimpinan dengan pegawai atau sesama pegawai, karena tanpa adanya komunikasi atau koordinasi yang baik maka di dalam setiap penyelesaian tugas akan timbul berbagai kendala di dalam pelaksanan tugas.

d. Dalam hal peningkatan kinerja pegawai negeri sipil, organisasi atau instansi perlu melakukan evaluasi-evaluasi yang bersifat menyeluruh kepada setiap pegawai yang ada sehingga pegawai menjadi sadar akan tugas dan tanggung jawab yang di milikinya.

\section{DAFTAR PUSTAKA}

\section{Buku}

Achmad, S. Ruky. 2002. Sistem Manajemen Kinerja. Gramedia Pustaka Utama. Jakarta.

Alfred, R. Latainer. 1983. Teknik Memimpin Pegawai Dan Pekerja. Terjemahan Imam Soejono. Aksara Baru. Jakarta.

Ardana, I Komang, Dkk. 2012, Manajemen Sumber Daya Manusia, Edisi Pertama, Cetakan Pertama, Penerbit : Graha Ilmu, Yogyakarta.

Arikunto Suharsini, 2010. Prosedur Penelitian: Suatu Pendekatan Praktek. Jakarta : Rineka Cipta.

Bangun Wilson, 2012, Manajemen Sumber Daya Manusia, Edisi Pertama, Cetakan Pertama, Penerbit : Erlangga, Jakarta.

Barnawi Dan Muhamad Arifin, 2012 Instrumen Pembinaan, Peningkatan Dan Penilaian Kinerja Guru Profesional. Ar- Ruzz Media, Yogyakarta.

Buchari Zainun. 1989. Manajemen Dan Motivasi. Balai Aksara. Jakarta.

Burgess, Robert G. 1988. Issues In Educational Research Qualitative Methods. Falmer Press, London.

Donnelly, James H., Gibson, James L., and Ivancevich, Jhon, 1994, Fundamental of management. Texas: Business Publication.

Dantes, Nyoman, 2012. Metode Penelitian, Andi Offset, Yogyakarta. 
Darsono dan Tjatjuk Siswanto, 2011, Manajemen Sumber Daya Manusia, edisi pertama, cetakan pertama, penerbit : Nusantara Consulting, Jakarta.

Effendy, Onong Uchjana. 1997. Ilmu Komunikasi (Teori Dan Praktek). Pt. Remaja Rosdakarya. Bandung., 2017. Ilmu Komunikasi (teori dan praktek). PT. Remaja Rosdakarya. Bandung.

Farmi Irham, 2013, Manajemen Kepemimpinan Teori dan Aplikasi, cetakan kedua, penerbit: Alfabeta, Bandung.

Fajar, Marhaeni. 2009. Ilmu Komunikasi Teori \& Praktek Edisi Pertama, Graha Ilmu Yoyakarta.

Gorda, 2004. Pengertian Dasar Manajemen Sumber Daya Manusia, Penerbit Widya Kriya. Gematama, Denpasar.

GR. Terry, 2000. Pengembangan Sumber Daya Manusia. Yogyakarta : Liberty.

Hakim Rahmat Budi, 2015, Manajemen dan Evaluasi Kinerja Karyawan, edisi pertama, cetakan pertama, Penerbit: Aswajaya Pressindo, Jakarta.

Handoko, T. Hani. 2000. Manajemen Personalia dan Sumber Daya Manusia, BPFE, Yogyakarta.

----------, 2012. Manajemen Personalia dan Sumber Daya Manusia. Yogyakarta : BPFE.

Hasibuan, Malayu.S.P 2005. Manajemen Sumber Daya Manusia. PT. Bumi Aksara, Jakarta

----------. 2006, Manajemen Sumber Daya Manusia, Edisi Revisi. : PT. Bumi Aksara, Jakarta.

--------- 2012. Manajemen Sumber Daya Manusia. PT. Bumi Aksara, Jakarta.

Iskandar. 2008. Metodologi Penelitian Pendidikan dan Sosial (Kualitatif dan Kuantitatif). Jakarta : Gaung Persada Press.

Kamus Umum Bahasa Indonesia. 1994. Pustaka Sinar Harapan. Jakarta.

Kartono, 2001. Manajemen Tenaga Kerja Dan Hubungan Kerja. Badung. Alumni Bandung

Mangkunegara, Anwar Prabu 2001 Manajemen Sumber Daya Manusia. Penerbit Remaja Rosdakarya, Bandung. 
2005. Manajemen Sumber Daya Manusia. Penerbit, Remaja Roskadarya, Bandung.

----------, 2010. Manajemen Sumber Daya Manusia. Penerbit, Remaja Roskadarya, Bandung.

----------, 2011. Manajemen Sumber Daya Manusia, Penerbit Remaja Roskadarya, Bandung.

Payaman J. Simanjuntak, 2005, Manajemen dan Evaluasi Kinerja, Jakarta: Lembaga Penerbit Fakultas Ekonomi UI.

Prawirosentono, Suryadi. 1999. Kebijakan Kinerja Karyawan. Yogyakarta. BPFE. Purwanto, Djoko. 2006. Komunikasi Bisnis. Erlangga. Jakarta

Rivai Veihzal, 2011. Manajemen Sumber Daya Manusia Untuk Perusahaan Dari Teori Ke Praktek, Penerbit : Rajagrafindo Persada, Jakarta.

Robbins, Stephen P., 2006 Perilaku Organisasi, PT Indeks, Kelompok Gramedia, Jakarta.

Ruslan, Rosady. 2008. Manajemen Public Relations dan Media Komunikasi. PT Rajagrafindo Persada, Jakarta.

Sadili Samsudin. 2005. Manajemen Sumber Daya Manusia. Pustaka Setia. Bandung

Sastrohadiwiryo, B. Siswanto, 2003, Manajemen Tenaga Kerja Indonesia. : Bumi Aksara, Jakarta -,2005. Manajemen Tenaga Kerja Indonesia Pendekatan Administratif Dan Operasional. Bumi Aksara, Jakarta.

-------- 2005. Manajemen Tenaga Kerja Indonesia,. Bumi Aksara, Jakarta.

Sembiring Masana, 2012, Budaya Kinerja Organisasi, (Perspektif Organisasi Pemerintah), Penerbit : Fokus Media, Bandung.

Sedarmayanti . 2001. Sumber Daya Manusia Dan Produktifitas Kerja.

Mandar Maju. Bandung.

2013, Manajemen Sumber Daya Manusia, Bandung: Refika. Aditama.

Simamora, Henry. 2003. Manajemen Sumber Daya Manusia, Edisi III. Jakarta STIE YKPN

Solihin, I. (2009) Pengantar Manajemen. Jakarta: Erlangga. 
Sondang P. Siagian, 1998. Manajemen Sumber Daya Manusia. Bumi Aksara Jakarta.

--------2006, Manajemen Sumber Daya Manusia Cetakan Ketiga Belas, Bumi Aksara, Jakarta

--------2009. Manajemen Sumber Daya Manusia. Bumi Aksara. Jakarta. 2008. Manajemen Sumber Daya Manusia . Bumi Aksara. Jakarta.

Stewart, L Tubss \& Sylvia Moss. 1974. Human Communication An Interpersonal Perspective New York: Bantam Books.

Sugiyono. 2012. Metode Penelitian Bisnis .Bandung : Alfabeta.

---------, 2013. Metode Penelitian Administrasi. Alpabeta, Bandung.

Suradinata, 1996. Ilmu Administrasi. Martha Indonesia, Jakarta.

Suranto A.W. 2005. Komunikasi Perkantoran. Media Wacana, Yogyakarta.

Sutrisno Edy. 2011. Manajemen Sumber Daya Manusia. Kencana, Jakarta.

The Liang Gie. 2002. Disiplin Organisasi. Jakarta : PT. Gunung Agung.

Timpe, A. Dale, 1998. Kinerja (Performance). Jakarta : PT. Elex Media Komputindo.

Umam, Khaerul (2010). Perilaku Organisasi. Bandung : Pusaka Setia.

Wexley, Kenneth N Dan Gary A. Yukl, 2000. Perilaku Organisasi Dan Psikologi

Perusahaan, Alih Bahasa: M. Shobarudin, Jakarta :Alih Bahasa: M. Shobarudin, Jakarta : Rineka Cipta

Wibowo 2010, Manajemen Kinerja. Edisi Ketiga, Penerbit Rajawali Pers, Jakarta. Wiryanto, 2004. Pengantar Ilmu Komunikasi. PT Gramedia Widiarsana Indonesia. Jakarta.

\section{Jurnal/Artikel/Tesis}

I Gusti Agung Ayu Maya Prabasari, Pengaruh Motivasi, Disiplin Kerja Dan Komunikasi Terhadap Kinerja Karyawan Pada Pt. Pln (Persero) Distribusi Bali. Jurnal Fakultas Ekonomi Universitas Udayana. Bali

Syamsu Alam, "Pengaruh Komunikasi, Motivasi, Dan Disiplin Kerja Terhadap Kinerja Pegawai Lembaga Penjaminan Mutu Pendidikan. Jurnal Universitas Tadulako. Sulteng. 
Vivi Nila Sari, Pengaruh Motivasi, Disiplin Kerja Dan Komunikasi Terhadap Kinerja Karyawan Pada Pt Adira Dinamika Multifinance Tbk Cabang Bukittinggi. Jurnal EKOBISTEK Fakultas Ekonomi, Vol. 6, No. 1, April 2017, Hal 119 - 146 Copyright@2016 by LPPM UPI YPTK Padang

Agung Karismadiyanto, S.E , Analisis Pengaruh Motivasi Kerja, Disiplin Kerja

Dan Komunikasi Terhadap Kinerja Karyawan. Jurnal Fakultas Ekonomi,Universitas Muhammadiyah Jember.

Lailatul Chodriyah, Analisis Pengaruh Motivasi, Disiplin Kerja Dan Komunikasi

Terhadap Kinerja Karyawan(Studi Pada Pt.Cito Putra Utama Cabang

Semarang J1 Indraprasta No 81). Jurnal Universitas Dian Nuswantoro. Semarang.

Agung Yatiningrum1; Supriyono2; Mochammad Ruslan3, Pengaruh Kedisiplinan Kerja, Komunikasi KerjaDan Motivasi Kerja Terhadap Kinerja Pegawai Dinas Peternakan Dan Kesehatan Hewan Kabupaten Probolinggo. Jurnal Fakultas Ekonomi Universitas Panca Marga Probolinggo.

Kadek Novianti, Ni Wayan Eka Mitariani, Pengaruh Disiplin Kerja Dan Komunikasi Terhadap Kinerja Karyawan Pada De Bakker Bakery Denpasar. Jurnal Fakultas Ekonomi Universitas Mahasaraswati Denpasar.

Kozaitunikmah, Pengaruh Komunikasi, Motivasi Dan Kedisiplinan Terhadap Kinerja Pegawai Di Dinas Pekerjaan Umum Kabupaten Ponorogo

Wilya Marlinda, Pengaruh Disiplin Kerja, Komunikasi Dan Motivasi Terhadap Kepuasan Kerja Serta Implikasinya Pada Kinerja Pegawai PT. PLN (Persero) Unit Induk Pembangunan VI".

\section{Peraturan Perundang-Undangan}

Undang-Undang Nomor 43 Tahun 1999 Tentang Perubahan Atas Undang-Undang Nomor 8 Tahun 1974 Tentang Pokok-Pokok Kepegawaian.

Undang-Undang Nomor 23 Tahun 2014 Tentang Pemerintahan Daerah. Peraturan Pemerintah No. 53 Tahun 2010 Tentang Disiplin Pegawai Negeri. 